\title{
IN VIVO SCREENING OF DITERPENE ALKALOIDS USING BDELLOID ROTIFER ASSAYS
}

\author{
Tivadar Kiss, ${ }^{1,2}$ Lilla Mácsai, ${ }^{3}$ Dezső Csupor, $, 1,2 *$ and Zsolt LÁszló DatKi ${ }^{3, *}$ \\ ${ }^{1}$ University of Szeged, Faculty of Pharmacy, Department of Pharmacognosy, \\ Eötvös u. 6, H-6720 Szeged, Hungary \\ ${ }^{2}$ University of Szeged, Interdisciplinary Centre for Natural Products, \\ Eötvös u. 6, H-6720 Szeged, Hungary \\ ${ }^{3}$ University of Szeged, Faculty of Medicine, Department of Psychiatry, \\ Kálvária sgt. 57, H-6725 Szeged, Hungary
}

(Received: May 17, 2017; accepted: June 13, 2017)

\begin{abstract}
The group of diterpene alkaloids contains numerous compounds with complex chemistry and diverse pharmacological activities. Beside toxicity, these compounds possess activity on the cardiovascular system, tumor cell lines and nervous system. The pharmacological properties have been described using in vitro and in vivo techniques; however, the bioactivities of many compounds have not thoroughly been studied. Here we report on the in vivo evaluation of ten diterpene alkaloids using bdelloid rotifer assays. Napelline exerted toxic effects on rotifers, while wide tolerance range was observed for other investigated compounds. Weak toxicity of songorine is supported by our experiment. Toxicological data for senbusine $\mathrm{A}$, senbusine $\mathrm{C}$, septentrioidine and hetisinone are reported for the first time.
\end{abstract}

Keywords: Diterpenoid alkaloids - toxicity - Aconitum - rotifers - Philodina acuticornis odiosa

\section{INTRODUCTION}

Diterpene alkaloids are secondary plant metabolites with a wide range of biological activity. The structures and substitution patterns of these compounds are highly diverse. Diterpene alkaloids are classified in order to the basic skeleton's carbon atom number $\left(\mathrm{C}_{18}\right.$ - bisnorditerpene alkaloids, $\mathrm{C}_{19}$ - norditerpene alkaloids, $\mathrm{C}_{20}$ - diterpene alkaloids) and by their ester groups.

Most of these compounds are highly toxic, while some of them exert beneficial pharmacological effects. Aconitine (3) is a well-known cardiotoxic compound. In various in vivo experiments, it is used for inducing arrhythmia. In vitro studies provide explanation for this effect: aconitine (3), together with other arrhythmogenic alkaloids (hypaconitine, mesaconitine) activates voltage-dependent $\mathrm{Na}^{+}$channels at their resting potential and inhibit their inactivation, resulting in a final inexcitability of the cells [3]. Interestingly, among diterpene alkaloids there are compounds with opposite, antiarrhythmic activity. Napelline (8) showed to exert low antiarrhythmic activity in rats [31], while delavaconitine (2) inhibited aconitine-induced arrhythmia

\footnotetext{
*Corresponding author; e-mail address: csupor.dezso@pharmacognosy.hu; datkizsolt@gmail.com
} 
[21]. In vitro study revealed the activity of acontine (3) and hetisione (9) on $\mathrm{Na}_{\mathrm{v}} 1.2$ sodium channel. Certain alkaloids act as competitive antagonists of aconitine (3). In the mechanism of the cardiac activity hERG and GIRK potassium channels are also involved. Aconitine (3) exerts cardiotoxicity through high hERG channel inhibition, while there is no such safety issue in case of songorine (10), because of its low inhibitory potential. Similarly, aconosine (1), neoline (4), senbusine A (5), senbusine $\mathrm{C}(6)$ and napelline (8) are having low potential on hERG channels. A comprehensive investigation of these compounds led to the development of a new group of antiarrhythmic drugs (e.g. lappaconitine hydrobromide) [28].

Among diterpene alkaloids there are many toxic compounds, however the toxicity does not exclude possible pharmacophore nature [4]. Furthermore, the pharmacological activities of several diterpene alkaloids are either poorly or not investigated at all. The aim of the current study was to investigate toxicity and pharmacological activity of bisnorditerpene alkaloids: aconosine (1), delavaconitine (2); norditerpene alkaloids: aconitine (3), neoline (4), senbusine A (5), senbusine C (6), septentrioidine (7); diterpene alkaloids: napelline (8), hetisinone (9) and songorine (10); using highthroughput viability and non-invasive bdelloid rotifer assay.

The pharmacological literature of these compounds revealed several different bioactivities beyond cardiac effects. The arrhythmia-inducing aconitine (3) showed to be potent apoptotic agent against pancreatic cancer (MIA PaCa-2, PANC-1) [15], breast cancer (MDA-MB-231) [12] and melanoma (B16 cell line) [9]. Neoline (4) and septentriodine (7) have been exerting cytotoxic activity in vitro [14, 17], however their effect is not supported by in vivo experiments.

Napelline (8) and songorine (10) exerted interesting effects in vitro and in vivo, as well. These alkaloids activate mesenchymal stem cells thereby increasing wound healing $[33,34]$. The anti-inflammatory effect of both compounds was comparable to diclofenac, in histamine-induced acute inflammation model in mice [20]. In rats, intraperitoneal administration of both compounds was shown to reduce painful reaction induced by acetic acid. However, the mechanism of analgesia is different. In case of songorine (10) it is assumed that the opioid system is involved [19]. Hetisinone (9) exerts anticholinesterase activity in vitro [1]. Several studies have reported central nervous system activities of these two compounds. Both exerted antidepressant activity in various animal models and showed to be effective stress modulators [18]. An extensive literature review, based on numerous in vivo and in vitro experimental data about diterpene alkaloids in general, lead to the understanding of the structure-activity relationship in case of cardiac [11], anticancer [13, 40] and analgesic [30] activity. The conclusion is contradictory in case of central nervous system activity. For example, songorine (10) acts in vivo as agonist on D2 [2] and $\mathrm{GABA}_{\mathrm{A}}$ receptors [16], however in vitro it exerts antagonistic activity [33]. In case of other alkaloids involved in the present experiments, no pharmacological data are available.

The in vivo studies, using living organisms are suitable to generat the most accurate data for pharmacological activities and toxicity assessment. Acceptance by the scientific community, reproducibility, sensitivity, economic are criteria which in vivo studies have to meet. Rotifers are widely used in toxicity assessment and they fulfill all 
aforementioned requirements [25]. Various Rotifera species have been used for method development, however, none of these were applied for the examination of diterpene alkaloids $[25,27]$.

\section{MATERIALS AND METHODS}

\section{Diterpene-alkaloids}

The examined diterpene alkaloids (Fig. 1) were isolated previously from A. toxicum Rchb. (1-2), A. napellus L. subsp. firmum (3-6, 8), A. vulparia Rchb. (7) and A. anthora L. (9-10) $[7,8]$. The purity $(\geq 95 \%)$ of the isolated compounds was confirmed by HPLC and ${ }^{1} \mathrm{H}$ NMR spectroscopy.

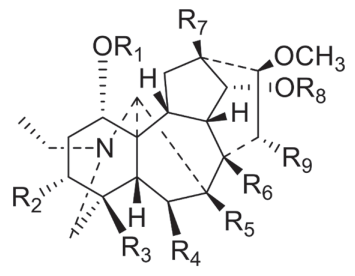

\begin{tabular}{llllllllll} 
Compound & $\mathbf{R}^{1}$ & $\mathbf{R}^{\mathbf{2}}$ & $\mathbf{R}^{\mathbf{3}}$ & $\mathbf{R}^{4}$ & $\mathbf{R}^{5}$ & $\mathbf{R}^{\mathbf{6}}$ & $\mathbf{R}^{\mathbf{7}}$ & $\mathbf{R}^{\mathbf{8}}$ & $\mathbf{R}^{\mathbf{9}}$ \\
\hline aconosine (1) & $\mathrm{CH}_{3}$ & $\mathrm{H}$ & $\mathrm{H}$ & $\mathrm{H}$ & $\mathrm{H}$ & $\mathrm{OH}$ & $\mathrm{H}$ & $\mathrm{H}$ & $\mathrm{H}$ \\
delavaconitine (2) & $\mathrm{CH}_{3}$ & $\mathrm{H}$ & $\mathrm{H}$ & $\mathrm{H}$ & $\mathrm{H}$ & $\mathrm{OH}$ & $\mathrm{OH}$ & $\mathrm{Bz}$ & $\mathrm{H}$ \\
aconitine (3) & $\mathrm{CH}_{3}$ & $\mathrm{OH}$ & $\mathrm{CH}_{2} \mathrm{OCH}_{3}$ & $\mathrm{OCH}_{3}$ & $\mathrm{H}$ & $\mathrm{OCOCH}$ & $\mathrm{OH}$ & $\mathrm{Bz}$ & $\mathrm{OH}$ \\
neoline (4) & $\mathrm{H}$ & $\mathrm{H}$ & $\mathrm{CH}_{2} \mathrm{OCH}_{3}$ & $\mathrm{OCH}_{3}$ & $\mathrm{H}$ & $\mathrm{OH}$ & $\mathrm{H}$ & $\mathrm{H}$ & $\mathrm{H}$ \\
senbusine A (5) & $\mathrm{H}$ & $\mathrm{H}$ & $\mathrm{CH}_{2} \mathrm{OCH}_{3}$ & $\mathrm{OH}$ & $\mathrm{H}$ & $\mathrm{OH}$ & $\mathrm{H}$ & $\mathrm{H}$ & $\mathrm{H}$ \\
senbusine C (6) & $\mathrm{H}$ & $\mathrm{H}$ & $\mathrm{CH}_{2} \mathrm{OCH}_{3}$ & $\mathrm{OCH}_{3}$ & $\mathrm{H}$ & $\mathrm{OH}$ & $\mathrm{H}$ & $\mathrm{H}$ & $\mathrm{OH}$ \\
septentriodine (7) & $\mathrm{CH}_{3}$ & $\mathrm{H}$ & $\mathrm{CH}_{2} \mathrm{Ant}$ & $\mathrm{OCH}_{3}$ & $\mathrm{OH}$ & $\mathrm{OH}$ & $\mathrm{H}$ & $\mathrm{OCH}$ & $\mathrm{OH}$
\end{tabular}

Bz: benzoyl Ant: anthranoyl

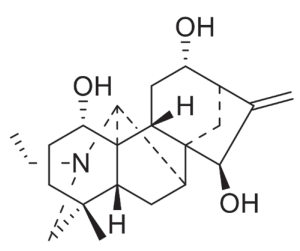

napelline (8)

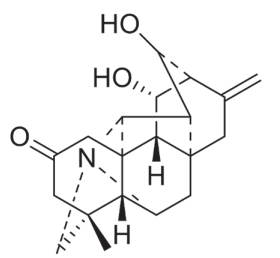

hetisinone (9)

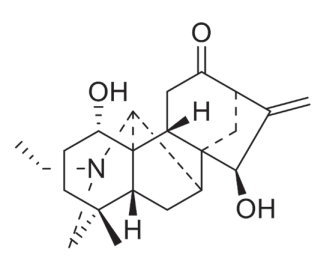

songorine (10)

Fig. 1. Chemical structures of examined compounds 


\section{Animals}

Philodina acuticornis odiosa (PA) and Cladophora aegagropila (CA) were obtained from a Hungarian aquaristic. Rotifer culturing methods were developed based on previous literature [23]. The animals were cultured in standard medium (SM), in data a supervised and semi-sterile environment. Clear cultures of PA were kept in standardized cell culturing flasks (cat. no.: 83.3910.302, Sarstedt AG \& Co., Germany), at $25^{\circ} \mathrm{C}$ and under a light/dark cycle of $12: 12$ hours. The exact composition of SM, matrix and food, along with the pattern of feeding and culturing were described at length by Oláh et al. [23].

Rotifers approximately 5 day after hatching (determined by body size; length $220 \pm$ $10 \mu \mathrm{m}$ and width $60 \pm 5 \mu \mathrm{m}), 1-2$ days before the beginning of the reproductive stage, were chosen. The selection process followed the harvesting protocols, published in ref [23].

\section{Non-invasive experimental monitoring assays}

The methodical protocols have been reported in our previous paper [23], therefore in this manuscript we only intend to give an overview of the applied techniques.

After $24 \mathrm{~h}$ of the standard isolation process, the rotifers were treated in a 384 wellplate (cat. no.: 3657, Corning Inc., USA; $\mathrm{n}=32$ ) with diterpene alkaloids $(1-8)$. For this in vivo experiment stock solutions were prepared with $1 \%$ aqueous DMSO. The stock solutions were added to standard media reaching $100 \mu \mathrm{M}$ final concentrations for diterpene alkaloid and 0.1\% DMSO content. Untreated control group (UC) were grown in SM, while control group (C) were kept in SM containing 0.1\% DMSO. The effect exerted by diterpene alkaloids were compared to $\mathrm{C}$. This treatment period lasted for 72 hours (toxicity interval), without feeding. From the fourth day began the daily monitoring period under restricted calorie state (yeast solution, $100 \mu \mathrm{g} / \mathrm{mL}$ ).

The viability of rotifers was assessed with three different assays utilizing video recordings with a Nikon D5500 DSLR camera.

\section{Toxicity and survival lifespan (TSL) assay}

The impact of the test compounds on the lifespan of unfed PA rotifers was assessed. The morphological viability markers, chosen for evaluation were adapted from Poeggeler et al. [24] were extended and defined in our previous work [23].

\section{Body size index (BSI) measurement}

Rotifers never stop growing; therefore the length/width of the animal in correlation with time (body size index; BSI) increases continuously within the species-specific limit. 


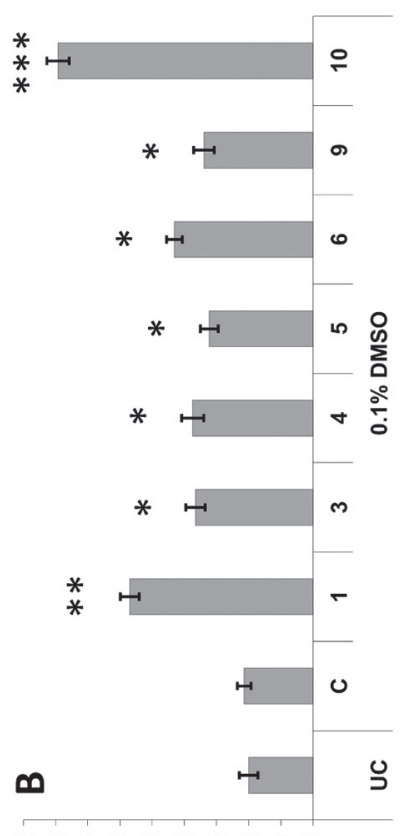

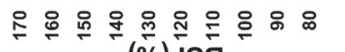
(\%) Isa

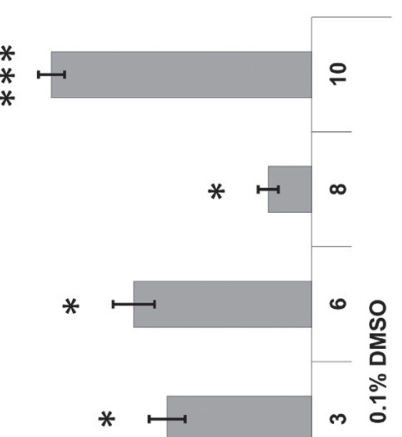

官

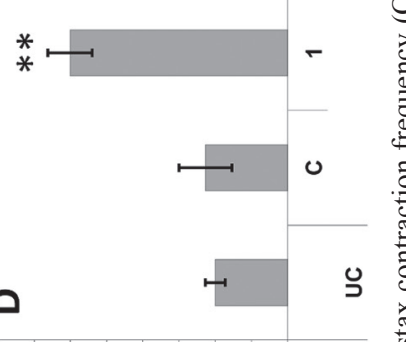

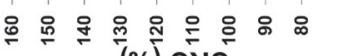

(\%) วบว

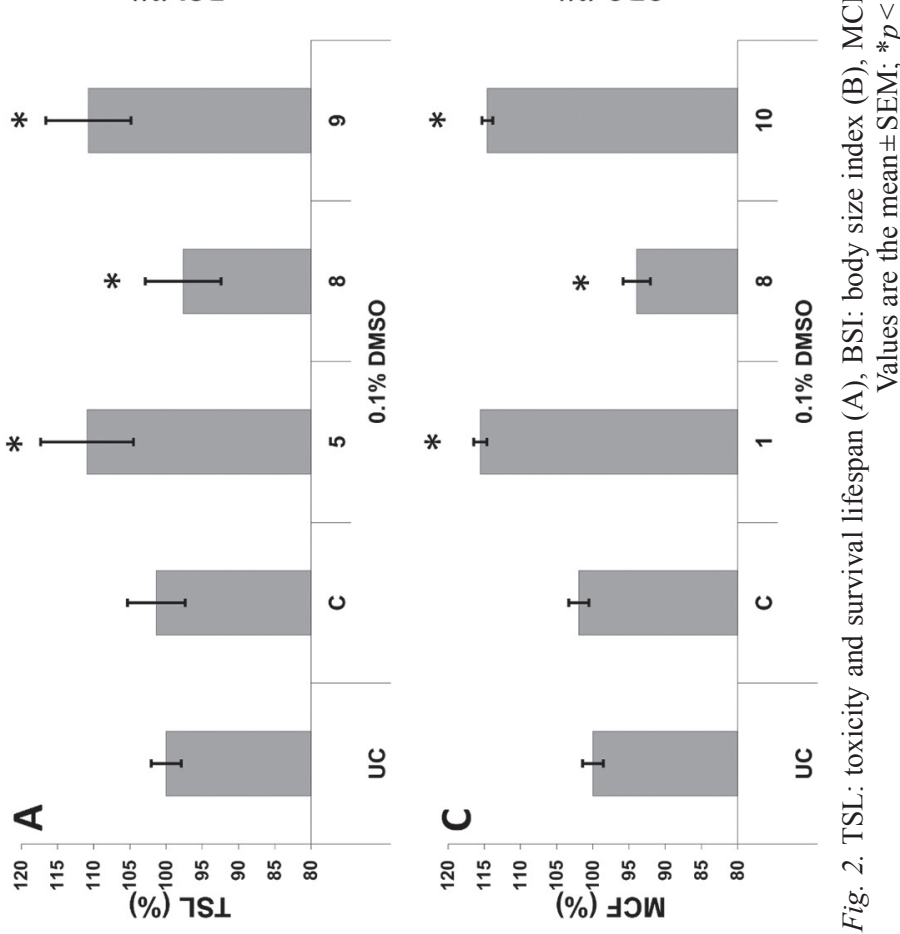

Acta Biologica Hungarica 68, 2017 


\section{Mastax contraction frequency (MCF) assay}

The mastax (pharynx) is part of the digestive system. To evaluate and standardize the viability of one-housed rotifers in our experiments, we developed the MCF (contraction/sec) as a quantitative viability marker.

\section{Invasive experimental monitoring assay}

\section{Cellular reduction capacity (CRC) assay}

The CRC gives information about the scale of reduction capacity and oxidative stress triggered by treatment in rotifers. For measuring the EZ4U Cell Proliferation Assay (non-radioactive cell proliferation, cytotoxicity and reduction capacity assay with XTT solution) was used (cat. no.: BI-5000; Biomedica Hungary). The absorbance was measured by a microplate-reader (Spectramax 384, Molecular Science, Hungary) set at $491 \mathrm{~nm}$ with $630 \mathrm{~nm}$ as a background reference.

\section{Data analyses}

Data are presented as means \pm SEM. Statistical evaluation and curve fitting were performed with Prism 7.0 (GraphPad Software) and with SPSS 23.0 software for Windows, using One-way ANOVA with post hoc Bonferroni test.

\section{RESULTS}

Ten diterpene alkaloids, belonging to the bisnor- $(1,2)$, nor- $(3-8)$ and diterpene $(9$, 10) were evaluated for their effects on PA viability (Table 1$)$.

All compounds, except napelline (8), increased the toxic survival lifespan value (TSL). Senbusine A (5) and hetisinone (9) resulted in significantly higher TSL assay values (Fig. 2A). Most of the compounds $(1,3-6,8-10)$ increased significantly the body size index (BSI) compared to the control group (Fig. 2B). Napelline (8) had slightly decreasing effect on BSI value. The mastax contraction frequency (MFC) was significantly decreased by napelline (8), and increased by aconosine (1) and songorine (10) (Fig. 2C). Significantly elevated cellular reduction capacity (CRC) was observed in case of treatment with aconosine (1), aconitine (3), senbusine C (6) and songorine (10), while napelline (8) significantly lowered this value (Fig 2D). 
Table 1

Viability parameters (mean $\pm \operatorname{SEM}, n=32$ )

\begin{tabular}{|l|c|c|c|c|}
\hline \multicolumn{1}{|c|}{ Compound } & TSL & BSI & MCF & CRC \\
\hline Aconosine (1) & $107.1 \pm 5.14$ & $136.9 \pm 2.92$ & $115.5 \pm 0.91$ & $140.1 \pm 6.09$ \\
\hline Delavaconitine (2) & $109.8 \pm 6.64$ & $113.9 \pm 3.19$ & $102.6 \pm 1.68$ & $115.9 \pm 6.57$ \\
\hline Aconitine (3) & $108.5 \pm 5.18$ & $116.5 \pm 3.00$ & $101.7 \pm 1.78$ & $119.9 \pm 4.96$ \\
\hline Neoline (4) & $109.3 \pm 7.04$ & $117.4 \pm 3.45$ & $102.0 \pm 2.05$ & $116.7 \pm 3.96$ \\
\hline Senbusine A (5) & $110.9 \pm 6.41$ & $112.2 \pm 2.73$ & $98.9 \pm 2.18$ & $115.5 \pm 5.54$ \\
\hline Senbusine C (6) & $107.1 \pm 5.42$ & $123.1 \pm 2.43$ & $101.4 \pm 2.03$ & $129.1 \pm 5.74$ \\
\hline Septentriodine (7) & $109.6 \pm 6.12$ & $114.5 \pm 3.05$ & $102.9 \pm 1.79$ & $111.1 \pm 4.79$ \\
\hline Napelline (8) & $97.6 \pm 5.24$ & $98.7 \pm 2.76$ & $93.9 \pm 1.87$ & $92.0 \pm 2.78$ \\
\hline Hetisinone (9) & $110.7 \pm 5.90$ & $113.9 \pm 3.00$ & $103.9 \pm 1.78$ & $116.4 \pm 6.35$ \\
\hline Songorine (10) & $108.4 \pm 6.28$ & $159.2 \pm 3.49$ & $114.6 \pm 0.74$ & $151.8 \pm 3.61$ \\
\hline
\end{tabular}

TSL - toxicity and survival lifespan; BSI - body size index; MCF - mastax contraction frequency; CRC - cellular reduction capacity.

\section{DISCUSSION}

We have measured the universal aspects of rotifers phenotype, to characterize Philodina acuticornis odiosa in terms of survival, health and behaviour. Decrease or increase in the experimental parameters of the rotifers are in correlation with the physiological state of individuals.

The investigated compounds proved to be non-toxic in these assays, except napelline (8), which reduced viability parameters. The wide tolerance range of alkaloids - including $\mathrm{C}_{18}, \mathrm{C}_{19}$ and $\mathrm{C}_{20}$ diterpene alkaloids - are reported for the first time. This conclusion is supported by the results of toxicity and survival lifespan (TSL) which provides mortality rate and the body size index (BSI). One norditerpenoid (5) and one diterpenoid (9) even increased the TSL. Only napelline (8) showed to be toxic by significantly decreasing the lifespan. Most of the investigated alkaloids increased the BSI, except napelline (8) which slightly decreased this value. The elevated mastax contraction frequency values showed no toxicity symptoms, since aconosine (1) and songorine (10) upregulated, while napelline (8) downregulated the metabolic state of the examined animals. The cellular reduction capacity gives information about the degree of reduction capacity and oxidative stress triggered by treatment. All compounds elevated cellular reduction capacity, except napelline (8).

Most of the examined compounds have been poorly investigated for their toxicity (Table 2). The median lethal dose $\left(\mathrm{LD}_{50}\right)$ in mice were available only for compound $1-4,8$ and 10 . According to these data, the most toxic compound is aconitine (3), while songorine (10) is the least toxic. The weak toxicity of songorine (10) is also supported by our experiment. The well-known aconitine (3) possesses high toxicity 
Table 2

$\mathrm{LD}_{50}$ data for the investigated compounds reported in literature $\left(\mathrm{NA}-\right.$ not available $\left.[6]^{\mathrm{a}, \mathrm{d}},[5]^{\mathrm{b}, \mathrm{e}},[26]^{\mathrm{c}},[10]^{\mathrm{f}}\right)$

\begin{tabular}{|l|c|c|c|c|}
\hline \multirow{2}{*}{\multicolumn{1}{|c|}{ Compound }} & \multicolumn{4}{|c|}{$\mathrm{LD}_{50}(\mathrm{mg} / \mathrm{kg})$} \\
\cline { 2 - 5 } & oral & intravenous & subcutaneous & intraperitoneal \\
\hline Aconosine (1) & NA & NA & NA & $154^{\mathrm{a}}$ \\
\hline Delavaconitine (2) & NA & $28.5^{\mathrm{b}}$ & $106^{\mathrm{b}}$ & NA \\
\hline Aconitine (3) & $1.0^{\mathrm{c}}$ & $0.10^{\mathrm{c}}$ & $0.27^{\mathrm{c}}$ & $0.27^{\mathrm{c}}$ \\
\hline Neoline (4) & NA & NA & NA & $150^{\mathrm{d}}$ \\
\hline Senbusine A (5) & NA & NA & NA & NA \\
\hline Senbusine C (6) & NA & NA & NA & NA \\
\hline Septentriodine (7) & NA & NA & NA & NA \\
\hline Napelline (8) & NA & $88^{\mathrm{e}}$ & NA & NA \\
\hline Hetisinone (9) & NA & NA & NA & NA \\
\hline Songorine (10) & NA & $142.5^{\mathrm{f}}$ & $630^{\mathrm{f}}$ & $485^{\mathrm{f}}$ \\
\hline
\end{tabular}

in vivo in rodents and mammalians, as well [26]. However, in our assay, napelline (8) showed to be the most toxic.

Since there is yet no toxicity data published for compounds 5-7 and 9, our present can be considered a priori report in vivo toxicity results.

In summary, this in vivo screening system, with four different methods, made possible to measure various conditions at different sensitivity levels of detection independently and/or simultaneously, providing a reliable and highly replicable screening method in pharmaceutical research.

\section{ACKNOWLEDGEMENTS}

Financial support from the National Research, Development and Innovation Office (OTKA K115796), Economic Development and Innovation Operative Programmw GINOP-2.3.2-15-2016-00012 and János Bolyai Research Scholarship of the Hungarian Academy of Sciences are gratefully acknowledged.

\section{REFERENCES}

1. Ahmad, H., Ahmad, S., Shah, S., Latif, A., Ali, M. (2017) Antioxidant and anticholinesterase potential of diterpenoid alkaloids from Aconitum heterophyllum. Bioorg. Med. Chem. 25, 3368-3376.

2. Ameri, A. (1998) Effects of the Aconitum alkaloid songorine on synaptic transmission and pairedpulse facilitation of CA1 pyramidal cells in rat hippocampal slices. Br. J. Pharmacol. 125, 461-468.

3. Ameri, A. (1998) The effects of Aconitum alkaloids on the central nervous system. Prog. Neurobiol. $56,211-235$.

4. Arcangeli, A., Becchetti, A. (2017) hERG channels: from antitargets to novel targets for cancer therapy. Clin. Cancer Res. 23, 3-5. 
5. Bisset, N. G. (1981) Arrow poisons in China. part II. Aconitum - botany, chemistry, and pharmacology. J. Ethnopharmacol. 4, 247-336.

6. Chen D.H. (1984) Biological activities and medicinal potenitialities of diterpene alkaloids. Chinese Trad. Herb. Med. 15, 180-184.

7. Csupor, D., Forgó, P., Wenzig, E. M., Bauer, R., Hohmann, J. (2008) Bisnorditerpene, norditerpene, and lipo-alkaloids from Aconitum toxicum. J. Nat. Prod. 71, 1779-1782.

8. Csupor, D., Forgó, P., Csedő, K., Hohmann, J. Csedö, K., Hohmann, J. (2006) $\mathrm{C}_{19}$ and $\mathrm{C}_{20}$ Diterpene alkaloids from Aconitum toxicum Rchb. Helv. Chim. Acta 89, 2981-2986.

9. Du, J., Lu, X., Long, Z., Zhang, Z., Zhu, X., Yang, Y. (2013) In vitro and in vivo anticancer activity of aconitine on melanoma cell line B16. Molecules 18, 757-767.

10. Dzhakhangirov, F. N., Sadritdinov, F. S. (1973) Antidepressive properties of the alkaloid songorine. Dokl. Akad. Nauk UzSSR 30, 39-40.

11. Dzhakhangirov, F. N., Sultankhodzhaev, M. N., Tashkhodzhaev, B., Salimov, B. T. (1997) Diterpenoid alkaloids as a new class of antiarrhythmic agents. Structure-activity relationship. Chem. Nat. Compd. $33,190-202$

12. Guo, B. (2011) Effects of osthole, psoralen, aconitine on breast cancer MDA-MB-231BO cell line inhibition in vitro. J. Chinese Integr. Med. 9, 1110-1117.

13. Hazawa, M., Takahashi, K., Wada, K., Mori, T., Kawahara, N., Kashiwakura, I. (2011) Structureactivity relationships between the Aconitum $\mathrm{C}_{20}$-diterpenoid alkaloid derivatives and the growth suppressive activities of Non-Hodgkin's lymphoma Raji cells and human hematopoietic stem/progenitor cells. Invest. New Drugs 29, 1-8.

14. de Inés, C., Reina, M., Gavín, J. A., González-Coloma, A. (2006) In vitro cytotoxicity of norditerpenoid alkaloids. Zeitschrift für Naturforsch. C, 61, 11-18.

15. Ji, B. L., Xia, L. P., Zhou, F. X., Mao, G. Z., Xu, L. X. (2016) Aconitine induces cell apoptosis in human pancreatic cancer via NF-kB signaling pathway. Eur. Rev. Med. Pharmacol. Sci. 20, 4955 4964.

16. Kőszegi, Z., Atlasz, T., Csupor, D., Szabadfi, K., Hohmann, J., Hernádi, K. (2007) Aconitum alkaloid songorine acts as a potent $\mathrm{GABA}_{\mathrm{A}}$ receptor agonist in the rat brain in vivo. Acta Physiol. Hung. 94, 367-368.

17. Liang, Y., Chen, Z., Liu, L., Liu, S., Zhang, G. (2009) Chemical constituents of planted Aconitum flavum. Zhongcaoyao 40, 862-865.

18. Nesterova, Y. V., Povetieva, T. N., Suslov, N. I., Semenov, A. A., Pushkarskiy, S. V. (2011) Antidepressant activity of diterpene alkaloids of Aconitum baicalense Turcz. Bull. Exp. Biol. Med. $151,425-428$.

19. Nesterova, Y. V., Povetieva, T. N., Suslov, N. I., Zyuzkov, G. N., Pushkarskii, S. V., Aksinenko, S. G., Schultz, E. E., Kravtsova, S. S., Krapivin, A. V. (2014) Analgesic activity of diterpene alkaloids from Aconitum baikalensis. Bull. Exp. Biol. Med. 157, 488-491.

20. Nesterova, Y. V., Povetieva, T. N., Suslov, N. I., Zyuzkov, G. N., Aksinenko, S. G., Pushkarskii, S. V., Krapivin, A. V. (2014) Anti-inflammatory activity of diterpene alkaloids from Aconitum baikalense. Bull. Exp. Biol. Med. 156, 665-668.

21. Povetieva, T. N., Suslov, N. I., Zhdanov, V. V., Hrichkova, T. Y., Udut, E. V., Chaykovskiy, A. S., Gaydamovich, N. N., Andreeva, T. I., Dygai, A. (2012) Regeneratory characteristics of complex extract and isolated diterpene alkaloids of Aconitum baikalense. Bull. Exp. Biol. Med. 152, 439-443.

22. Niitsu, K., Chin, S., Fukuyama, K., Mihashi, H. (1992) Diterpene alkaloid and pharmaceuticals containing diterpene alkaloids for treatment of heart failure. Jpn. Kokai Tokkyo Koho. (JP04026676A): $7 \mathrm{pp}$.

23. Oláh, Z., Bush, A. I., Dávid, A., Gálik, B., Ivitz, E., Mácsai, L., Karman, Z., Janka, Z., Datki, Zs. (2017) Novel in vivo experimental viability assays with high sensitivity and throughput capacity using a bdelloid rotifer. Ecotoxicol. Environ. Saf. 144, 115-122.

24. Poeggeler, B., Durand, G., Polidori, A., Pappolla, M. A., Vega-Naredo, I., Coto-Montes, A., Boker, J., Hardeland, R., Pucci, B. (2005) Mitochondrial medicine: neuroprotection and life extension by the 
new amphiphilic nitrone LPBNAH1 acting as a highly potent antioxidant agent. J. Neurochem. 95, 962-973.

25. Rico-Martínez, R., Arzate-Cárdenas, M. A., Robles-Vargas, D., Pérez-Legaspi, I. A., Alvarado-Flores, J., Santos-Medrano, G. E. (2016) Rotifers as models in toxicity screening of chemicals and environmental samples. In: Larramendy, M. L., Soloneski, S. (eds) Invertebrates - Experimental Models in Toxicity Screening. InTech; pp. 57-99.

26. Singhuber, J., Zhu, M., Prinz, S., Kopp, B. (2009) Aconitum in Traditional Chinese Medicine-A valuable drug or an unpredictable risk? J. Ethnopharmacol. 126, 18-30.

27. Snell, T. W., Persoone, G. (1989) Acute toxicity bioassays using rotifers. I. A test for brackish and marine environments with Brachionus plicatilis. Aquat. Toxicol. 14, 65-80.

28. Tai, C. J., El-Shazly, M., Wu, T. Y., Wu, T. Y., Lee, K. T., Csupor, D., Hohmann, J., Chang, F. R., Wu, Y. C. (2015) Clinical aspects of Aconitum preparations. Planta Med. 81, 1017-1028.

29. Wada, K., Ohkoshi, E., Zhao, Y., Goto, M., Morris-Natschke, S. L., Lee, K. H. (2015) Evaluation of Aconitum diterpenoid alkaloids as antiproliferative agents. Bioorg. Med. Chem. Lett. 25, 1525-1531.

30. Wang, J. L., Shen, X. L., Chen, Q. H., Qi, G., Wang, W., Wang, F. P. (2009) Structure-analgesic activity relationship studies on the $\mathrm{C}_{18^{-}}$and $\mathrm{C}_{19}$-diterpenoid alkaloids. Chem. Pharm. Bull. 57, 801-807.

31. Yunusov, M. S. (2011) Antiarrhythmic agents based on diterpenoid alkaloids. Russ. Chem. Bull. 60, 633-638.

32. Zhao, X. Y., Wang, Y., Li, Y., Chen, X. Q., Yang, H., Yue, J. M., Hu, G. Y. (2003) Songorine, a diterpenoid alkaloid of the genus Aconitum, is a novel $\mathrm{GABA}_{\mathrm{A}}$ receptor antagonist in rat brain. Neurosci. Lett. 337, 33-36.

33. Zyuz'kov, G. N., Krapivin, A. V., Nesterova, Y. V., Povetieva, T. N., Zhdanov, V. V., Suslov, N. I., Fomina, T. I., Udut, E. V., Miroshnichenko, L. A., Simanina, E. V., Semenov, A. A., Kravtsova, S., Dygai, A. M. (2012) Mechanisms of regeneratory effects of Baikal Aconite diterpene alkaloids. Bull. Exp. Biol. Med. 153, 847-851.

34. Zyuz'kov, G. N., Povet'eva, T. N., Semenov, A. A., Zhdanov, V. V., Krapivin, A. V., Nesterova, Y. V., Suslov, N. I., Fomina, T. I., Dygai, A. M. (2013) Napelline as wound-healing medication. Russ., (RU2475259C1): 8 pp. 